\title{
PENGEMBANGAN PEMBELAJARAN IPS MI BERBASIS MODEL PROLEM BASED LEARNING DAN BERORIENTASI KEKINIAN
}

Tri Rachma Zakiya Ningtyas

Prodi Pendidikan Guru Madrasah Ibtidaiyah - Fakultas Agama Islam Universitas Islam Darul 'Ulum Lamongan

J1. Airlangga No. 03 Sukodadi Lamongan

Email: trirachmazakiya@unisda.ac.id

\begin{abstract}
Social studies learning is generally only limited to remembering facts and not making students feel involved in the reality that occurs in their social environment. Teachers are still relying on abstract and non-appreciated concepts to be followed up by students. The teacher still positions students as passive listeners. This results in the critical reasoning of students to be frozen and difficult to solve the social problems they face later.

Through the use ofmodels Problem Based Learning (PBL), social studies learning can develop quantitatively and qualitatively. PBL presents a variety of authentic and meaningful problem situations to students, which can serve as a springboard for investigation and investigation. The application of the PBL model at the primary education level has limitations in constructing students' thinking and may not lead to a complex social problem that requires analysis from various disciplines.

Emphasis on the material of Social Sciences in SD / MI should be more on the real facts that occur relating to human interaction with the geographical, social, cultural and human economic environment. Learning activities with PBL models are designed to provide a learning experience in terms of physical and mental. The pattern of development through the PBL model is by recording meaningful knowledge (inquiry) by yourself. Social studies learning becomes an opportunity to learn students about social knowledge that can be used as an evaluation in facing future state life.

In practice, the PBL model uses a variety of learning resources that are structured, not monotonous, and mixed. Included in it can use retention activities by presenting material that is involved in teaching material for human interaction related to the natural, social, cultural and economic environment.
\end{abstract}

Keywords: Development of learning, social studies, problem Based on Learning 


\begin{abstract}
Abstrak
Pembelajaran IPS umumnya hanya sebatas mengingat suatu fakta-fakta dan tidak sampai menjadikan peserta didik merasa terlibat dalam realitas yang terjadi di lingkungan sosialnya. Guru masih bertopang pada konsep yang abstrak dan tidak terapresiasi untuk dapat ditindaklanjuti oleh peserta didik. Guru masih memposisikan peserta didik sebatas sebagai pendengar pasif. Hal ini mengakibatkan nalar kritis peserta didik menjadi beku dan sulit memecahkan persoalan sosial yang mereka hadapi nantinya.

Melalui penggunaan model Problem Based Learning (PBL), pembelajaran IPS dapat berkembang secara kuantitatif dan kualitatif. PBL menyuguhkan berbagai situasi masalah yang autentik dan bermakna kepada peserta didik, yang dapat berfungsi sebagai batu loncatan untuk investigasi dan penyelidikan. Penerapan model PBL di tingkat pendidikan dasar memiliki batasan dalam mengkonstruksikan pemikiran anak didik dan tidak boleh menggiring ke suatu permasalahan sosial yang rumit dan memerlukan analisis dari berbagai disiplin ilmu.

Penekanan materi Ilmu Pengetahuan Sosial di SD/MI seharusnya lebih pada fakta-fakta riil yang terjadi yang berkenaan dengan interaksi manusia dengan lingkungan geografis, sosial, budaya, dan ekonomi manusia. Kegiatan pembelajaran dengan model PBL dirancang untuk memberikan pengalaman belajar dari segi fisik dan mental. Pola pengembangan melalui model PBL, adalah dengan mencatat sendiri pengetahuan yg bermakna (inkuiri). Pembelajaran IPS menjadi kesempatan untuk memperbelajarkan peserta didik tentang pengetahuan sosial yang dapat dijadikan evaluasi dalam menyongsong kehidupan bernegara di masa akan datang.

Dalam pelaksanaannya, model PBL menggunakan berbagai sumber belajar yang terstruktur, tidak monoton, dan berbaur. Termasuk di dalamnya dapat menggunakan kegiatan retensi dengan menyajikan materi yang mengena dalam mengajarkan materi interaksi manusia berkaitan dengan lingkungan alam, sosial, budaya dan ekonomi.
\end{abstract}

Kata kunci: Pengembangan pembelajaran, IPS, Problem Based Learning

\title{
A. PENDAhuluan
}

Realitas pembelajaran Ilmu pengetahuan sosial (IPS) di sekolah, umuumnya masih banyak dijumpai fenomena anak-anak menghafal materi di buku teks pelajaran. Para guru mapel tersebut masih menganggap IPS hanya seperangkat fakta-fakta yang bisa dikuasai hanya dengan dihafalkan. Sejalan dengan hal tersebut, pembelajaran yang diberikan para guru hanya sekedar transfer of knowledge. peserta didik dalam 
proses pembelajaran sebatas sebagai pendengar pasif dengan sikap diam, duduk manis mendengarkan, merekam ceramah, atau hanya mencatat apa yang disampaikan oleh guru. Guru menyajikan pembelajaran yang bertopang pada konsep yang abstrak dan sulit diterima peserta didik secara utuh dan mendalam, sehingga pemahaman peserta didik hanya terbatas pada konsep yang diajarkan dan lebih banyak sebagai sesuatu yang diingat dan tidak terapresiasi untuk dapat ditindaklanjuti oleh peserta didik. Peserta didik hanya pasif menunggu intruksi dari guru tentang apa-apa yang harus dipelajari dan apa yang harus dilakukan. Apabila hal ini dilakukan secara terusmenerus, maka kondisi seperti tidak akan dapat mengembangkan kemampuan peserta didik. Nalar kritis mereka menjadi beku dan sulit memecahkan permasalahan yang mereka hadapi. Berdasarkan fenomena ini, penulis merasa perlu untuk menawarkan pengembangan pembelajaran berbasis model Problem Based Learning dan berorientasi kekinian pada proses kegiatan belajar mengajar (KBM).

\section{B. PEMBahasan}

Kegiatan pembelajaran dirancang untuk memberikan pengalaman belajar yang melibatkan proses mental dan fisik melalui interaksi antar peserta didik, peserta didik dengan guru, lingkungan, dan sumber belajar lainnya dalam rangka pencapaian Kompetensi Dasar (KD). Peningkatan kualitas belajar mengajar dibutuhkan jika menghendaki hasil belajar yang baik. Kualitas belajar-mengajar akan terwujud jika ada upaya dari guru untuk berusaha seoptimal mungkin merealisasikan aktualisasi belajar mengajar yang lebih menekankan keterlibatan peserta didik di dalam kegiatan belajar mengajar, karena dengan cara itulah pengajaran mempunyai peluang yang besar untuk mewujudkan dan meningkatkan mutu pendidikan.

Pengembangan kegiatan pembelajaran Ilmu Pengetahuan Sosial (IPS) menggunakan pendekatan saintifik atau pendekatan berbasis keilmuan atau dapat menggunakan model pembelajaran. Pola pengembangan adalah model yang menggambarkan kedudukan serta peran guru dan peserta didik dalam proses pembelajaran. Istilah pengembangan dapat bermakna kuantitatif dan kualitatif. Pengembangan pembelajaran IPS secara kuantitatif artinya bagaimana menjadikan waktu pembelajaran di kelas yang terbatas dapat lebih meluas dan merata pengaruhnya baik dalam maupun di luar madrasah. Secara kualitatif bagaimana menjadikan pembelajaran IPS lebih baik, bermutu, dan lebih tanggap dalam merespons dan mengantiipasi berbagai tantangan hidup dan kehidupan. Berpikir pengembangan mengajak seseorang untuk berpikir kreatif dan inovatif dalam melakukan perubahan sebagai akibat dari keprihatinan terhadap kondisi dan eksistensi IPS yang ada, yang diikuti dengan pertumbuhan dan pembaharuan atau perbaikan serta ditingkatkan secara terus-menerus untuk dibawa ke posisi yang lebih ideal. Selama ini IPS dipahami sebagai dimensi keilmuan yang hanya berisi materi 
jenis pengetahuan faktual. Materi yang berkaitan dengan nama-nama objek, nama tempat, nama orang, lambang, peristiwa sejarah, dan nama bagian atau kompenen suatu benda.

Secara historis perkembangan pembelajaran dapat diklasifikasikan sebagai berikut: Pertama, pola pembelajaran yang didominasi oleh guru sebagai satu-satunya sumber belajar, penentu metode belajar, bahkan termasuk penilaian kemajuan belajar peserta didik; Kedua, perkembangan pembelajaran telah mempengaruhi pola pembelajaran. Guru yang semula sebagai satu-satunya sumber belajar, peranannya mulai dibantu media pembelajaran, sehingga proses pembelajaran tampak berubah lebih efisien; Ketiga, pembelajaran terus mengalami perkembangan sejalan dengan kemajuan ilmu pengetahuan dan teknologi.

Penggunaan model Problem Based Learning (PBL) adalah salah satu bentuk pola pengembangan pembelajaran IPS secara kuantitatif dan kualitatif. Menurut Rusman PBL adalah pembelajaran yang menuntut aktivitas mental peserta didik dalam memahami suatu konsep, prinsip, dan keterampilan melalui situasi atau masalah yang disajikan di awal pembelajaran. Berdasarkan uraian di atas dapat disimpulkan bahwa Problem Based Learning merupakan model pembelajaran yang melibatkan akif peserta didik dengan masalah nyata yang dimulai pada awal pembelajaran dengan menggembangkan cara berpikir dan ketrampilan yang lebih tinggi. ${ }^{1}$ Hal ini juga sesuai dengan yang dikemukakan oleh Arends, bahwa PBL merupakan salah satu pembelajaran yang memungkinkan dikembangkannya keterampilan berpikir peserta didik menjadi aktif. ${ }^{2}$ Problem Based Learning menyuguhkan berbagai situasi masalah yang autentik dan bermakna kepada peserta didik, yang dapat berfungsi sebagai batu loncatan untuk investigasi dan penyelidikan. Belajar tidak hanya sekedar menghafal tetapi peserta didik harus mengkonstruksi pengetahuan mereka sendiri (konstruktivistik). Dimana peserta didik belajar dari mengalami, mencatat sendiri pola-pola bermakna dari pengetahuan baru dan bukan diberi begitu saja oleh guru, serta membiasakan peserta didik memecahkan masalah, menemukan sesuatu yang berguna.

Belajar merupakan proses aktif guna merangkai berbagai pengalaman, menggunakan masalah-masalah nyata yang terdapat di lingkungannya untuk berlatih keterampilan-keterampilan yang lebih spesifik. Namun perlu diketahui dalam pembelajaran anak, tidak boleh menekankan pada praktek-praktek yang diarahkan untuk menjadikan anak-anak seperti orang dewasa dalam pemikirannya. Boleh saja menggiring mereka untuk menghadapi situasi sosial, namun sebatas dalam konstruksi berpikir yang lebih sederhana. Tidak relevan jika peserta didik usia MI disuruh

\footnotetext{
${ }^{1}$ Rusman, Model-model Pembelajaran (Jakarta: Rajawali Press, 2010), hlm.:242

${ }^{2}$ Ricard I. Arends, Learning to Teach, Ninth Edition (New York: McGrawHill, 2012), hlm.396
} 
memecahkan permasalahan politisasi agama, BLBI, dan sebagainya, yang mana memerlukan struktur pemikiran yang kompleks. Penggiringan pola pemikiran anak tentunya disesuaikan dengan tingkat kedalaman dan keluasan materi IPS SD/MI.

Problem Based Learning suatu model pembelajaran yang menggunakan masalah sebagai titik awal untuk mengakui isi pengetahuan baru. Peserta didik belajar menggunakan masalah autentik tertentu untuk belajar konten (isi) pelajaran dan sebaliknya peserta didik juga belajar keterampilan khusus untuk memecahkan masalah dengan menggunakan sarana konten pembelajaran. ${ }^{3}$ Dengan demikian, kegiatan pembelajaran tidaklah bersifat pasif dan berpusat pada guru. Melalui model pembelajaran ini, guru didorong lebih memposisikan dirinya menjadi fasilitator dan penanya daripada penyaji dan pendemo informasi.

Penekanan materi Ilmu Pengetahuan Sosial di SD/MI seharusnya lebih pada fakta-fakta riil yang terjadi yang berkenaan dengan interaksi manusia dengan lingkungan geografis, sosial, budaya, dan ekonomi manusia. Tidak hanya membahas teori sosial secara definitif semata. Memang tidak dipungkiri perlu adanya pengetahuan definisi istilah-istilah dari pengetahuan sosial, namun tidak seharusnya guru terjebak di dalamnya dan menjadikannya suatu beban pembelajaran yang harus dikuasai peserta didik dengan cara dihafal. Peran guru adalah membantu peserta didik menemukan fakta, konsep, atau prinsip bagi diri mereka sendiri, bukan memberikan ceramah atau sebagai aktor dalam seluruh kegiatan pembelajaran di kelas. Sebagai contoh dalam kompetensi dasar ranah kognitif yang diajarkan kepada peserta didik kelas 4 (empat), "Memahami manusia dalam dinamika interaksi dengan lingkungan alam, sosial, budaya, dan ekonomi”. Di awal kegiatan pembelajaran, guru dapat mengajukan sebuah permasalahan untuk dapat merangsang peserta didik berpikir aktif, seperti; Negara Indonesia adalah negara yang kaya dan terdiri dari banyak suku dengan bahasa daerah yang berbeda-beda, dengan apa antar suku di Indonesia dapat berkomunikasi antara satu dengan lainnya? Selanjutnya dalam kegiatan inti pembelajaran, guru dapat meluruskan atau menambahkan jawaban yang benar dan di akhir kegiatan guru selalu mengajak peserta didik untuk dapat menggunakan bahasa Indonesia yang baik dan benar minimal di sekolah. Guru juga hendaknya selalu mengingatkan bahwa bahasa Indonesia adalah bahasa Persatuan yang mempersatukan antar etnis, ras, suku di Indonesia. Sebagai intermezzo di sela-sela pembelajaran, guru dapat memperkenalkan dan mengajak bernyanyi "Kolam Susu" atau lagu-lagu populer yang dapat menjadikan anak bangga memiliki negeri ini. Berbagai kegiatan tersebut sejalan untuk memenuhi salah satu dari kompetensi ranah psikomotorik dari

\footnotetext{
${ }^{3}$ Muslimin Ibrahim, Pembelajaran Berdasarkan Masalah Latar Belakang, Konsep Dasar, dan contoh implementasinya (Surabaya: Unesa University Press, 2005), hlm.5
} 
kelas 4 (empat), yakni "Menceritakan manusia dalam hubungannya dengan lingkungan geografis tempat tinggalnya".

Model Problem Based Learning dilandasi oleh teori Konstruktivisme. Sesuai dengan prinsip dari teori Konstruktivisme, untuk benar-benar mengerti dan dapat menerapkan ilmu pengetahuan, peserta didik harus bekerja untuk memecahkan masalah, menemukan sesutu bagi diri mereka sendiri (inkuiri), dan selalu bergulat ide-ide.Tugas pendidikan tidak hanya menuangkan atau menjejalkan sejumlah informasi ke dalam benak peserta didik, tetapi mengusahakan bagaimana agar konsep-konsep penting dan sangat berguna tertanam kuat dalam benak mereka.

Ketika mengajarkan IPS merupakan kesempatan memperbelajarkan peserta didik tentang sejarah dari bangsa ini agar dapat membekali peserta didik menjadi dalam menghadapi situasi sosial dalam kehidupan berbangsa di masa yang akan datang. Pada tingkat SD/MI, sejarah tentang bangsa Indonesia diberikan di kelas 5 (lima) melalui kompetensi dasar "Mengenal perubahan dan keberlanjutan yang terjadi dalam kehidupan manusia dan masyarakat Indonesia pada masa penjajahan, masa tumbuhnya rasa kebangsaan, serta perubahan dalam aspek sosial, ekonomi, pendidikan dan budaya".

Dalam mengajarkan sejarah tersebut, guru dapat menyisipkan pesan moral tentang pentingnya kerukunan dan ketidakserakahan. Sebagaimana yang disampaikan Bapak Prof. KH. Abdul Ghofur, bahwa sebelum adanya penjajahan, masyarakat nusantara saling berperang untuk merebutkan kekuasaan. Bahkan peperangan terjadi antara umat seagama, seperti kisah kesultanan Demak sepeninggalnya Raden Fatah. Sehingga melihat kekacauan di bumi Indonesia, akhirnya Allah menurunkan cobaan dengan didatangnya kaum penjajah. Berabad-abad lamanya rakyat Indonesia tidak dapat menikmati kemerdekaan, sampai pada akhirnya ketika rakyat Indonesia mau bersatu, dapat merebut kemerdekaan. ${ }^{4}$

Dari sejak dini, peserta didik perlu ditanamkan rasa memiliki persepsi yang baik mengenai apa yang mereka pelajari. Menurut Fleming dan Levie -sebagaimana yang dikemukakan Muhaimin-, persepsi adalah suatu proses yag bersifat kompleks yang menyebabkan orang dapat menerima atau meringkas informasi yang diperoleh dari lingkungannya. ${ }^{5}$ Untuk membentuk persepsi yang akurat mengenai stimuli yang diterima serta mengembangkannya menjadi suatu kebiasaan, peserta didik perlu latihan-latihan dalam bentuk dan kondisi situasi yang bermacam-macam agar peserta didik tetap dapat mengenal pola stimuli itu, meskipun disajikan dalam bentuk yang

\footnotetext{
${ }^{4}$ Siaran di radio Persada, Paciran pada tanggal 5 Juli 2017

${ }^{5}$ Muhaimin, dkk, Pardigma Pendidikan Islam, Upaya Mengefektifkan Pendidikan Agama Islam di Sekolah (Bandung: Rosdakarya, 2001), hlm. 137
} 
baru. ${ }^{6}$ Hal ini sesuai dengan prinsip Problem Based Learning dirancang berdasarkan masalah kehiduan rill kehidupan yang bersifat ill-structured, terbuka, dan mendua. ${ }^{7}$ Problem Based Learning dapat membangkitkan minat peserta didik, nyata dan sesuai untuk membangun kemampuan intelektual, serta memiliki gagasan bahwa pembelajaran dapat dicapai jika kegiatan pendidikan dipusatkan pada tugas-tugas atau permasalahan yang autentik, relevan dan dipresentasikan dalam satu konteks. Terlebih setelah diterapkannya kurikulum 2013, mapel IPS disajikan dengan menggunakan pendekatan saintifik melalui mengamati, menanya, mencoba, menalar, dan mengkomunikasikan. Sebagaimana Hosnan menyatakan, langkah pendekatan saintifik menganut beberapa ranah pencapaian hasil belajar yang tertuang pada kegiatan pembelajaran. Proses pembelajaran menyentuh tiga ranah, yaitu sikap, pengetahuan, dan keterampilan. ${ }^{8}$

Dalam menerapkan pembelajaran PBL, beberapa hal yang dapat direncanakan, antara lain:

a. Menentukan tujuan pembelajaran umum dan tujuan pembelajaran khusus. Pembelajaran PBL dirancang untuk membantu mencapai tujuan-tujuan seperti: memperkaya keterampilan-keterampilan dan penyelidikan, memahami peranperan orang dewasa, dan membantu peserta didik menjadi mandiri.

b. Merencanakan situasi masalah yang sesuai. Terdapat lima kriteria penting untuk menentukan bahwa situasi masalah itu dapat dikatakan baik untuk digunakan dalam pembelajaran PBL, yaitu: pertama, masalah itu harus autentik. Artinya lebih berakar pada pengalaman dunia nyata peserta didik daripada prinsip-prinsip disiplin akademik tertentu. Kedua, masalah itu seharusnya terdefinisikan secara agak longgar atau tidak ketat dan menghadapkan pada nuansa misteri dan teka-teki. Ketiga, masalah itu harus bermakna bagi peserta didik dan sesuai dengan perkembangan intelektual peserta didik. Keempat, masalah seharusnya cukup luas untuk menuntaskan tujuan-tujuan pembelajaran mereka, namun cukup terbatas agar menjadikan pelajaran itu layak diselesaiakan dalam keterbatasan waktu, ruang, dan sumber daya. Kelima, masalah tersebut harus menguntungkan bagi upaya kelompok, tidak menghalangi upaya kelompok.

c. Merencanakan sumber daya dan merencanakan logistik. Pembelajaran PBL mendorong peserta didik bekerja dengan berbagai bahan dan alat, sebagian diantaranya tersedia di kelas, lainnya berada di perpustakaa atau laboratorium

${ }^{6}$ Maksudin, Pengembangan Metodologi Pendidikan Agama Islam Pendekatan Dialektik (Yogyakarta: Pustaka Pelajar, 2015), hlm.165

${ }^{7}$ Muhaimin, dkk, Pardigma..., hlm.137

${ }^{8}$ M. Hosnan, Pendekatan saintifik dan konstektual dalam Pembelajaran Abad 21 (Jakarta: Ghalia Indonesia, 2014), hlm.32 
computer, dan juga terdapat di luar sekolah. Tugas utama guru dalam PBL adalah mengorganisasikan sumber daya dan perencanaan logistik penunjang penyelidikan peserta didik.

Arends menyatakan bahwa sintaks pembelajaran berdasarkan masalah terdiri dari lima fase utama, fase-fase tersebut terujuk pada tahapan-tahapan yang praktis yang dilakukan dalam kegiatan pembelajaran Problem Based Learning ${ }^{9}$, yang dapat dijelaskan dalam tabel berikut.

Tabel 1. Fase Pembelajaran PBL

\begin{tabular}{|l|l|}
\hline \multicolumn{1}{|c|}{ Fase } & \multicolumn{1}{c|}{ Perilaku Guru } \\
\hline $\begin{array}{l}\text { Fase 1: } \text { orientasi } \\
\text { Memberikan permasalahan } \\
\text { tentang } \\
\text { kepada siswa. }\end{array}$ & $\begin{array}{l}\text { Guru membahas tujuan pembelajaran, } \\
\text { mendiskripsikan berbagai kebutuhan logistik } \\
\text { penting, dan memotivasi siswa untuk terlibat } \\
\text { dalam kegiatan mengatasi masalah. }\end{array}$ \\
\hline $\begin{array}{l}\text { Fase 2: } \\
\text { Mengorganisasikan siswa } \\
\text { untuk meneliti. }\end{array}$ & $\begin{array}{l}\text { Guru membantu siswa untuk mendefinisikan } \\
\text { dan mengorganisasikan tugas- tugas belajar } \\
\text { yang terkait dengan permasalahannya. }\end{array}$ \\
\hline $\begin{array}{l}\text { Fase 3: } \\
\text { Membantu }\end{array}$ & $\begin{array}{l}\text { Guru mendorong siswa untuk mendapatkan } \\
\text { informasi yang tepat, melaksanakan } \\
\text { eksperimen dan mencari penjelasan dan solusi. }\end{array}$ \\
\hline $\begin{array}{l}\text { Fase 4: } \\
\text { Mengembangkan dan } \\
\text { mempresentasikan artefak } \\
\text { dan exhibit. }\end{array}$ & $\begin{array}{l}\text { Guru membantu siswa dalam merencanakan } \\
\text { dan menyiapkan artefak- artefak yang sesuai } \\
\text { laporan, rekaman video, dan model-model, } \\
\text { serta membantu mereka } \\
\text { menyampaikannya kepada orang lain. }\end{array}$ \\
\hline $\begin{array}{l}\text { Fase 5: } \\
\text { Menganalisis dan } \\
\text { mengevaluasi proses } \\
\text { mengatasi masalah. }\end{array}$ & $\begin{array}{l}\text { Guru membantu siswa untuk melakukan reflex } \\
\text { terhadap investigasinya dan proses- proses } \\
\text { yang mereka gunakan. }\end{array}$ \\
\hline
\end{tabular}

Problem Based Learning atau pembelajaran berbasis masalah sebagai suatu konteks bagi siswa untuk belajar tentang cara berfikir kritis dan ketrampilan pemecahan masalah, serta untuk memperoleh pengetahuan dan konsep yang esensial dari materi pelajaran. Tujuan yang terpenting dari model PBL yang adalah membuat siswa menjadi pembelajar yang otonom dan mandiri. Peserta didik dituntut untuk lebih aktif dalam menyelesaikan tugas-tugas dalam proses pembelajaran. Guru hanya

${ }^{9}$ Ricard I. Arends, Learning..., hlm.56-60 
berperan dalam membimbing, mengarahkan dan mendorong siswa untuk mencari jawaban terhadap masalah nyata oleh siswa sendiri sehingga siswa dapat belajar menyelesaikan masalah dan tugas secara mandiri dalam kehidupan sehari-hari.

Untuk lebih jelasnya, ciri-ciri pembelajaran berorientasi masalah dapat dikemukakan sebegai berikut:

a. Tujuan pembelajaran dirancang untuk dapat merangsang dan melibatkan siswa dalam pola pemecahan masalah, sehingga siswa diharapkan mampu mengembangkan keahlian belajar dalam bidangnya secara langsung dalam mengidentifikasi masalah;

b. Adanya keberlanjutan permasalahan dalam hal ini ada dua tuntutan yang harus dipenuhi yaitu:pertama, masalah harus memunculkan konsep dan prinsip yang relevan dalam kandungan materi yang dibahas. Kedua, permasalahan harus bersifat real sehingga dapat melibatkan siswa tentang kesamaan dengan suatu permasalahan;

c. Adanya presentasi permasalahan, siswa dilibatkan dalam mempresentasikan permasalahan sehingga siswa merasa memiliki permasalahan tersebut;

d. Pengajar berperan sebagi tutor dan fasilitator.Dalam posisi ini maka peran dari fasilitator adalah mengembangkan kreatifitas berpikir para siswa dalam bentuk keahlian dalam pemecahan masalah dan membantu siswa untuk menjadi mandiri. berikut: ${ }^{10}$

Menurut Rusman, karakteristik Problem Based Learning adalah sebagai

a. Permasalahan menjadi starting point dalam belajar

b. Permasalahan yang diangkat adalah permasalahan yang ada di dunia nyata yang tidak terstruktur

c. Permasalahan membutuhkan perspektif ganda (multiple perspective)

d. Permasalahan, menantang pengetahuan yang dimiliki oleh peserta didik, sikap, dan kompetensi yang kemudian membutuhkan identifikasi kebutuhan belajar dan bidang baru dalam belajar

e. Belajar pengarahan diri menjadi hal yang utama

f. Pemanfaatan sumber pengetahuan yang beragam, penggunaannya, dan evaluasi sumber informasi merupakan proses yang esensial dalam PBL

g. Belajar adalah kolaboratif, komunikasi, dan kooperatif

h. Pengembangan ketrampilan inquiry dan pemecahan masalah sama pentingnya dengan penguasaan isi pengetahuan untuk mencari solusi darri sebuah permasalahan

\footnotetext{
${ }^{10}$ Rusman, Model..., hlm.232
} 
i. Keterbukaan proses dalamPBL meliputi sintesi dan integrasi dari sebuah proses belajar, dan

j. PBL melibatkan evaluasi dan review pengalaman peserta didik dan proses belajar.

Mengingat prosedur dari pembelajaran berbasis masalah, mula-mula peserta didik melalukakn identifikasi masalah, dikala muncul sebuah situasi yakni situasi masalah yang dapat muncul sebagai hasil dari pengamatan terhadap fenomena atau gejala yang "menarik" atau yang "aneh". Ada bagian dari perstiwa atau fenomena itu yang belum dapat dijelaskan secara masuk akal. Maka perlu menetapkan atau merumuskan apa masalah yang ingin dipecahkan.

Selanjutnya peserta didik mengajukan hipotesis atau jawaban sementara yang bersifat tentatif, yang diduga dapat menjawab permasalahan di atas. Hipotesis berfungsi untuk memprediksi atau menjelaskan sebab-sebab dari masalah yang telah dirumuskan. Dikatakan sementara karena hipotesis ini dapat dibentuk berdasarkan akal sehat, dugaan murni, spekulasi, imajinasi, maupun asumsi tertentu. Dalam kesempatan tertentu kegiatan ini mencakup pula studi kepustakaan.

Kemudian dilanjutkan dengan pengumpulan data. Langkah ini dimaksudkan untuk mengumpulkan fakta atau data sebanyak mungkin dari lapangan dengan teknik-teknik tertentu misalnya wawancara, kuesioner, observasi, dan sebagainya. Data merupakan fakta yang sudah diolah dan disajikan dalam bentuk dan cara yang sistematis. Bentuknya dapat berupa statistik, gambar, tabel, grafik, dan dokumendokumen. Sedangkan fakta biasanya sering disebut data mentah. Fakta atau data inilah yang harus diolah pada langkah berikutnya. Selanjutnya dilanjutkan dengan menganalisis data. Langkah ini dimaksudkan pertama-tama untuk menjawab masalah yang telah ditetapkan pada langkah awal. Dengan kata lain untuk membuktikan apakah hipotesis yang dirumuskan sebelumnya benar atau tidak.

Evaluasi pembelajaran dalam model PBL dilaksanakan secara autentik melalui penilaian proses dan hasil. Penilaian proses dapat dilaksanakan melalui mencermati keaktifan peserta didik. Nilai lebih diberikan bagi peserta didik yang berani menjawab pertanyaan guru, aktif dalam diskusi, tanggap dalam mengemukakan masalah di lapangan dan sigap dalam memberikan solusi. Penilaian hasil dapat dilakukan melalui proyek atau portofolio. Penilaian Portofolio yang notabene adalah penilaian berkelanjutan yang didasarkan pada kumpulan informasi yang bersifat reflektif-integratif yang menunjukkan perkembangan kemampuan peserta didik dalam satu periode tertentu. Semisal guru dapat menggunakan portofolio dokumentasi dari hasil mengamati fenomena situasi sosial di masyarakat. 
Secara umum dapat dikemukakan bahwa kelebihan dari Problem Based Learning adalah sebagai berikut: ${ }^{11}$

a. Peserta didik akan terbiasa menghadapi masalah (Problem Posing) dan merasa tertantang untuk menyelesaikan masalah, tidak hanya terkait dengan pembelajaran dalam kelas, tetapi juga menghadapi masalah yang ada dalam kehidupan sehari- hari (real world)

b. Memupuk solidaritas sosial dengan terbiasa berdiskusi dengaan teman- teman sekelompok kemudian berdiskusi dengan teman- teman sekelasnya

c. Makin mengakrabkan guru dengan peserta didik

d. Karena ada kemungkinan suatu masalah harus diselesaikan peserta didik melalui eksperimen hal ini juga akan membiasakan peserta didik dalam menerapkan metode eksperimen.

Disamping keunggulan, strategi Problem Based Learning juga memiliki kelemahan, diantaranya:

a. Ketika peserta didik kurang berminat belajar, maka akan sulit dipecahkan masalah tersebut, karena enggan mencoba.

b. Keberhasilanya membutuhkan cukup waktu persiapan.

c. Tanpa pemahaman mereka berusaha memecahkan masalah yang dipelajari, maka mereka tidak akan belajar apa yang mereka ingin pelajari.

d. Penilaian dan evaluasi dilakukan dengan mengukur kegiatan peserta didik, dengan penilaian kegiatan dan peragaan hasil melalui presentasi. Penilaian kegiatan diambil melalui pengamatan, kemudian kemampuan peserta didik dalam merumuskan pertanyaan, dan upaya menciptakan solusi permasalahan.

Melalui model pembelajaran Problem Based Learning dapat meningkatkan hasil belajar peserta didik dalam mata pelajaran Ilmu Pengetahuan Sosial dengan mengembangkan kemampuan dan kreativitas peserta didik. Karena model pembelajaran Problem Based Learning dipandang lebih efektif, variatif dan inovatif, karena model pembelajaran tersebut dapat meningkatkan keterlibatan peserta didik dan dapat menumbuhkan kreativitas dan kemandirian peserta didik di dalam proses pembelajaran untuk memperoleh informasi, pengalaman serta mendapat pengetahuan baru dari penemuan-penemuan dalam proses pembelajaran yang dilakukan.

Dalam mengembangkan perangkat pembelajaran yang berorietnasi pada PBL, maka perlu adanya mengidentifikasi materi pokok/pembelajaran yang menunjang

${ }^{11}$ Warsono, Pembelajaran Aktif: Teori dan Asesmen (Bandung: Remaja Rosdakarya, 2013), hlm. 152 
pencapaian kompetensi dasar, salah satunya dengan mempertimbangkan relevansi dengan karakter daerah.

Aktivitas peserta didik untuk masing-masing pengalaman belajar diuraikan sebagai berikut:

a. Peserta didik mengamati fenomena dengan indera (mendengarkan, melihat, membau, meraba, mengecap) dengan atau tanpa alat (untuk menemukan masalah). Fenomena tersebut dapat berupa benda, peristiwa atau keadaan yang sebenarnya, dapat juga yang dikemas dalam bentuk gambar, foto, teks (berita, iklan, puisi, cerpen), film, video dan sebagainya.

b. Peserta didik merumuskan pertanyaan tentang hal-hal yang tidak diketahui dari fenomena yang diamati (dapat dilengkapi dengan merumuskan hipotesis). Pada aktivitas ini, guru diharapkan dapat membimbing dan membantu peserta didik agar dapat merumuskan pertanyaan dengan baik. Pertanyaan yang dirumuskan sekurang-kurangnya mencakup indikator yang ditetapkan untuk pembelajaran tersebut.

c. Peserta didik mengumpulkan informasi/data dengan (berbagai) teknik yang sesuai, misalnya; eksperimen, pengamatan, wawancara, survei, dan membaca dokumen-dokumen.

d. Peserta didik mengolah informasi/data yang sudah dikumpulkan untuk menjawab pertanyaan dan menarik kesimpulan.

e. Peserta didik menyampaikan jawaban atas pertanyaan (kesimpulan) berdasarkan hasil penalaran/asosiasi informasi/data secara lisan dan/atau tertulis, dan dapat dilanjutkan dengan mencipta.

f. Peserta didik menginovasi, mencipta, mendisain model, rancangan, produk (karya) berdasarkan pengetahuan yang telah dibangun atau diperoleh. Tahap mencipta diperlukan untuk menjadikan peserta didik mengetahui manfaat pengetahuannya dan memfasilitasi peserta didik memperoleh pengetahuan berpikir tingkat tinggi (mencipta).

Dalam memenuhi kebutuhan pendidikan karakter tentunya harus ditunjang dengan sumber belajar yang berkualitas. Untuk menunjang pembelajaran aktif, sumber belajar tidak bisa dipersempit hanya sebatas buku. Pengertian sumber belajar adalah segala sesuatu dapat berupa orang, objek, lingkungan, atau peristiwa, baik yang direncanakan maupun yang dapat dimanfaatkan oleh pembelajar, baik secara terpisah maupun gabungan, untuk kepentingan pencapaian tujuan pembelajaran. Mengingat pembelajaran bersifat Student centered, sumber belajar secara luas dapat dikategorikan sebagai berikut:

a. Tempat atau lingkungan alam sekitar yaitu dimana saja seseorang dapat melakukan belajar atau proses perubahan tingkah laku maka tempat itu dapat 
dikategorikan sebagai tempat belajar yang berarti sumber belajar. Dalam konteks mata pelajaran IPS yang memuat pembahasan terkait interaksi manusia, tempat atau lingkungan alam sekitar yang dapat dijadikan sumber belajar tidak hanya sebatas perpustakaan, museum, dan tempat-tempat formal lainnya. Peserta didik dapat belajar mengamati interaksi manusia dalam kaitannya dengan kehidupan sosial, budaya, dan ekonomi di tempat-tempat seperti; pasar, tempat pembuangan sampah, kolong jembatan, dan lain sebagainya.

b. Benda yaitu segala benda yang memungkinkan terjadinya perubahan tingkah laku bagi peserta didik, maka benda itu dapat dikategorikan sebagai sumber belajar. Misalnya situs, candi, globe (bola dunia), peta, dan sebagainya.

c. Orang yaitu siapa saja yang memiliki keahlian tertentu di mana peserta didik dapat belajar sesuatu, maka yang bersangkutan dapat dikategorikan sebagai sumber belajar. Misalnya guru, ahli geologi, polisi, dan ahli-ahli lainnya.

d. Bahan yaitu segala sesuatu yang berupa teks tertulis, cetak, rekaman elektronik, web, dan lain lain yang dapat digunakan untuk belajar.

e. Buku yaitu segala macam buku yang dapat dibaca secara mandiri oleh peserta didik dapat dikategorikan sebagai sumber belajar. Misalnya buku pelajaran, buku teks, kamus, ensiklopedi, fiksi dan lain sebagainya.

f. Fenomena atau fakta yang terjadi, misalnya peristiwa kerusuhan, peristiwa bencana, dan peristiwa lainnya yang mana guru dapat menjadikan peristiwa atau fakta sebagai sumber belajar. Fenomena atau fakta yang ditemukan oleh peserta didik justru menjadi pembelajaran yang bermakna, karena dapat memaksimalkan fungsi otak untuk menganalisa.

Menurut Sa'dun Akbar, sumber belajar dapat dikatakan baik, selain harus berorientasi pada student centered, juga harus berpihak pada ideologi Bangsa dan Negara. ${ }^{12}$ Buku ajar sebagai sumber belajar yang baik, harus mendukung ketakwaan kepada Tuhan yang Maha Esa; mendukung pertumbuhan nilai kemanusiaan; mendukung kesadaran akan kemajemukan masyarakat; mendukung tumbuhnya rasa nasionalisme; mendukung tumbuhnya kesadaran hokum, dan mendukung rasa berfikir logis. ${ }^{13}$ Buku Ajar selayaknya menjadi pelopor anak-anak untuk menanamkan rasa cinta tanah air. Idealnya guru membuat buku ajar sendiri atau paling tidak berusaha selektif mencari buku ajar sendiri yang dijual di toko buku. Pembelajaran Inkuiri yang ditekankan PBL, tidak lantas kemudian guru melepas peserta didik tanpa memperhatikan dari sumber belajar mana mereka mendapatkan informasi. Tidak etis guru mengandalkan materi ajar yang tersaji di buku LKS hlm. 34

${ }^{12}$ Sa'dun Akbar, Instrumen Perangkat Pembelajaran. Bandung: Remaja Rosdakarya, 2013, ${ }^{13}$ Ibid., hlm. 34 
murahan yang ditawarkan oleh pedagang keliling dan mengorbankan aspek akurasi. Keakuratan antara lain dapat dilihat dari aspek:kecermatan penyajian, benar memaparkan hasil penelitian, dan tidak salah mengutip pendapat pakar. Akurasi dapat pula dilihat dari dan teori dengan perkembangan mutakhir, dan pendekatan keilmuan yang bersangkutan. Semisal dalam pembelajaran IPS kelas V dengan tema "Bangga sebagai Bangsa Indonesia". Kompetensi dasar yang melandasi tema tersebut adalah "Memahami manusia Indonesia dalam bentuk-bentuk dan sifat dinamika interaksi dengan lingkungan alam, sosial, budaya, dan ekonomi”.

Sepintas dari KD tersebut dianggap hanya sekedar kompetensi pengetahuan yang dapat dikuasai oleh peserta didik melalui hafalan. Namun ketika hanya dihafalkan akan menjadikan materi tersebut tidak akan mengena bagi peserta didik. Kompetensi Dasar selanjutnya disebutkan adalah mengidentifikasi karakteristik geografis Indonesia sebagai negara kepulauan/maritim dan agraris serta pengaruhnya terhadap kehidupan ekonomi, sosial, budaya." Untuk menjadikan rasa bangga menjadi warga negara Indonesia dan merasa memiliki tanah air Indonesia, guru dapat menjelaskan bahwa Indonesia punya lautan yang sangat luas yang terdapat berbagai macam spesies ikan di dalamnya. Bahkan negara tetangga iri dengan kekayaan di Indonesia sampai terkadang mencuri ikan di perairan Indonesia. Tindak lanjut dari proses pembelajaran ini, selanjutnya di kegiatan pembelajaran ke depannya, guru dapat mengajak peserta didik untuk membawa bekal nasi yang terdapat ikan laut sehingga peserta didik timbul rasa kebanggaan bisa menikmati kekayaan negeri. sebelumnya dalam kegiatab awal pembelajaran,guru dapat menanyai peserta didik "mengapa kita bangga memiliki negara Indonesia?"

Padahal ketika seorang guru dapat berpikir kreatif maka dalam kegiatan pendahuluan dapat melakukan retensi pembelajaran. Dalam menerapkan pembelajaran yang kontekstual dan sekaligus memiliki keterampilan untuk memecahkan masalah, perlu adanya retensi belajar. Berdasarkan temuan Thomburg sebagaimana yang dikemukakan Maksudin- dalam pembelajaran perlu diperhatikan prinsip-prinsip untuk meningkatkan retensi belajar seperti yang diungkapkan, menunjukkan bahwa a) isi pembelajaran yang bermakna akan lebih mudah diingat dibandingkan dengan isi pembelajaran yang tidak bermakna; 2) benda yang lebih jelas dan konkret akan lebih mudah diingat daripada benda yang bersifat abstrak; 3) retensi akan lebih baik untuk isi oembelajaran yang bersifat kontekstual, 4) tidak ada perbedaan antara retensi dengan apa yang telah dipelajari peserta didik yang mempunyai berbagai tingkatan IQ.

Prinsip retensi dalam pembelajaran IPS tentunya sangat tepat untuk digunakan karena ilmu pengetahuan ini sarat dengan muatan-muatan berkaitan dengan lingkungan geografis, sosial, budaya, dan ekonomi. Contoh-contoh kegiatan yang dapat memberi stimulus agar peserta didik memiliki rasa bangga bertanah air 
Indonesia, yakni; membawa atau membuat makanan khas daerah untuk dimakan bersama, membiasakan menggunakan benda-benda produk Indonesia. Siswa dapat diminta setiap kali pertemuan untuk membawa gambar benda bersejarah sebagai penilaian portofolio.

Kecenderungan pembelajaran dewasa ini adalah sistem belajar mandiri dalam program terstruktur. Untuk itu perlu dipersiapkan sumber belajar secara khusus yang memungkinkan dapat digunakan peserta didik secara langsung. Sumber belajar jenis ini lazimnya berupa media yang dipersiapkan oleh kelompok guru dengan tenaga ahli media, sehingga hasilnya dapat dimanfaatkan sebagai media pembelajaran. Guru dan ahli media berinteraksi dengan pelajar berdasarkan satu tanggung-jawab bersama. Sejalan dengan meningkatnya kebutuhan kualitas tenaga guru yang profesional, salah satu jalan yang dapat ditempuh adalah dengan membekali para guru agar mampu mengembangkan pembelajaran yang sistematis dan terprogram seperti buku ajar, modul, atau media lain yang dapat menunjang kegiatan pembelajaran. Dengan demikian, peserta didik lebh mandiri dalam melakukan kegiaan pembelajaran. Pola dasar pembelajaran tersebut masih mungkin dikombinasikan supaya proses pembelajaran sebagai suatu sistem dapat berjalaan secara kebih efektif dan efisien.

Dalam prakteknya tidak ada pola pembelajaran yang baku dan dapat digunakan dalam berbagai kondisi pembelajaran. Berbagai pola tersebut saling berbaur dan melengkapi satu dengan yang lainnya. Secara operasional, penerapan pola pembelajaran tersebut mempunyai ciri pokok, antara lain adalah sebagai berikut:

1. Fasilitas fisik sebagai perantara penyajian informasi

2. Sistem pembelajaran dan pemanfaatan fasilitas yang merupakan komponen terpadu; Adanya pilihan yang memungkinkan terjadinya; a) perubahan fisik tempat belajar, b) aktivitas peserta didik yang lebih maniri, c) perlunya kerjasama lintas disiplin ilmu seperti ahli instruksional, ahli media pembelajaran, d) perubahan peranan dan kecakapan mengajar, e) keluwesan waktu dan tempat belajar.

Dalam sebuah pengembangan pembelajaran IPS, tentunya perlu untuk mengevaluasi kesulitan yang dialami dan memprediksi kesulitan yang akan dihadapi. Kesulitan-kesulitan yang dihadapi dalam pelaksanaan pembelajarannya. Guru harus berupaya untuk menjadikan peserta didiknya semangat belajar. Guru dapat merancang proses pembelajaran yang menjadikan lingkungan sekitarnya sebagai sumber belajar. Pembelajaran dimulai dari apa yang sudah diketahui oleh peserta didik sesuai dengan konteksnya dan baru dilanjutkan pada konteks yang lebih luas.

Pembelajaran dibuat oleh guru seharusnya berorientasi pada pengembangan ilmu pengetahuan dan teknologi, dan nilai-nilai kehidupan masa kini. Hal ini bukan berarti tidak mempelajari masa lalu dan masa depan. Ilmu pengetahuan, teknologi, 
dan nilai-nilai pada masa lalu digunakan sebagai pijakan untuk pengembangannya di masa kini. Ilmu pengetahuan dan teknologi di masa kini dimanfaatkan peserta didik untuk mempersiapkan diri menghadapi berbagai kemungkinan pengembangan ilmu pengetahun, teknologi, dan nilai-nilai kehidupan di masa depan. Pembelajarna dikondisikan dengan mempertimbangkan penerapan teknologi informasi dan komunikasi secara terintegrasi, sistematis, dan efektif sesuai dengan situasi dan kondisi. Tantangan ke depan sebagai pembelajar IPS, peserta didik harus mampu menghadapi revolusi kehidupan di masyarakat. Permasalahan sosial yang kompleks yang sering terjadi dalam dinamika kehidupan.

\section{KESIMPULAN}

Melalui penggunaan model Problem Based Learning (PBL), pembelajaran IPS dapat berkembang secara kuantitatif dan kualitatif. PBL menyuguhkan berbagai situasi masalah yang autentik dan bermakna kepada peserta didik, yang dapat berfungsi sebagai batu loncatan untuk investigasi dan penyelidikan. Guru didorong lebih menjadi fasilitator dan penanya daripada penyaji dan pendemo informasi. Meskipun demikian, penerapan model PBL di tingkat pendidikan dasar memiliki batasan dalam mengkonstruksikan pemikiran anak didik dan tidak boleh menggiring ke suatu permasalahan sosial yang rumit dan memerlukan analisis dari berbagai disiplin ilmu.

Penekanan materi Ilmu Pengetahuan Sosial di SD/MI seharusnya lebih pada fakta-fakta riil yang terjadi yang berkenaan dengan interaksi manusia dengan lingkungan geografis, sosial, budaya, dan ekonomi manusia. Tidak hanya membahas teori sosial secara definitif semata. Memang tidak dipungkiri perlu adanya pengetahuan tentang definisi istilah-istilah dari pengetahuan sosial, namun tidak seharusnya guru terjebak di dalamnya dan menjadikannya suatu beban pembelajaran yang harus dikuasai peserta didik dengan cara dihafal.

Kegiatan pembelajaran dengan model PBL dirancang untuk memberikan pengalaman belajar dari segi fisik dan mental. Pola pengembangan melalui model PBL, adalah dengan mencatat sendiri pengetahuan yg bermakna (inkuiri). Pembelajaran IPS menjadi kesempatan untuk memperbelajarkan peserta didik tentang pengetahuan sosial yang dapat dijadikan evaluasi dalam menyongsong kehidupan bernegara di masa akan datang.

Dalam pelaksanaannya, model PBL menggunakan berbagai sumber belajar yang terstruktur, tidak monoton, dan berbaur antara satu dan lainnya. Termasuk di dalamnya dapat menggunakan kegiatan retensi dengan menyajikan materi yang mengena dalam mengajarkan materi interaksi manusia berkaitan dengan lingkungan alam, sosial, budaya dan ekonomi. 


\section{DAFTAR PUSTAKA}

Akbar Sa'dun, 2013. Instrumen Perangkat Pembelajaran. Bandung: Remaja Rosdakarya.

Arends, Ricard I. 2012. Learning to Teach, Ninth Edition, New York: McGrawHill.

Hosnan, M. 2014. Pendekatan saintifik dan konstektual dalam Pembelajaran Abad 21. Jakarta: Ghalia Indonesia.

Ibrahim, Muslimin. 2005. Pembelajaran Berdasarkan Masalah Latar Belakang, Konsep Dasar, dan contoh implementasinya. Surabaya: Unesa University Press.

Maksudin, 2015. Pengembangan Metodologi Pendidikan Agama Islam Pendekatan Dialektik, Yogyakarta: Pustaka Pelajar.

Muhaimin, dkk, 2001. Pardigma Pendidikan Islam, Upaya Mengefektifkan Pendidikan Agama Islam di Sekolah, Bandung: Rosdakarya.

Rusman. 2010. Model-model Pembelajaran. Jakarta: Rajawali Press.

Warsono, 2013. Pembelajaran Aktif: Teori dan Asesmen, Bandung: Remaja Rosdakarya. 